\title{
Self-employment as a means to women's economic self- sufficiency: Women Venture's business development program
}

Katharine McKee

Sara Gould

Ann Leonard

Follow this and additional works at: https://knowledgecommons.popcouncil.org/departments_sbsr-pgy

Part of the Entrepreneurial and Small Business Operations Commons, Family, Life Course, and Society Commons, Gender and Sexuality Commons, Inequality and Stratification Commons, and the Work, Economy and Organizations Commons How does access to this work benefit you? Let us know!

\section{Recommended Citation}

McKee, Katharine, Sara Gould, and Ann Leonard. 1993. "Self-employment as a means to women's economic self-sufficiency: Women Venture's business development program," SEEDS no. 15. New York: Population Council. 


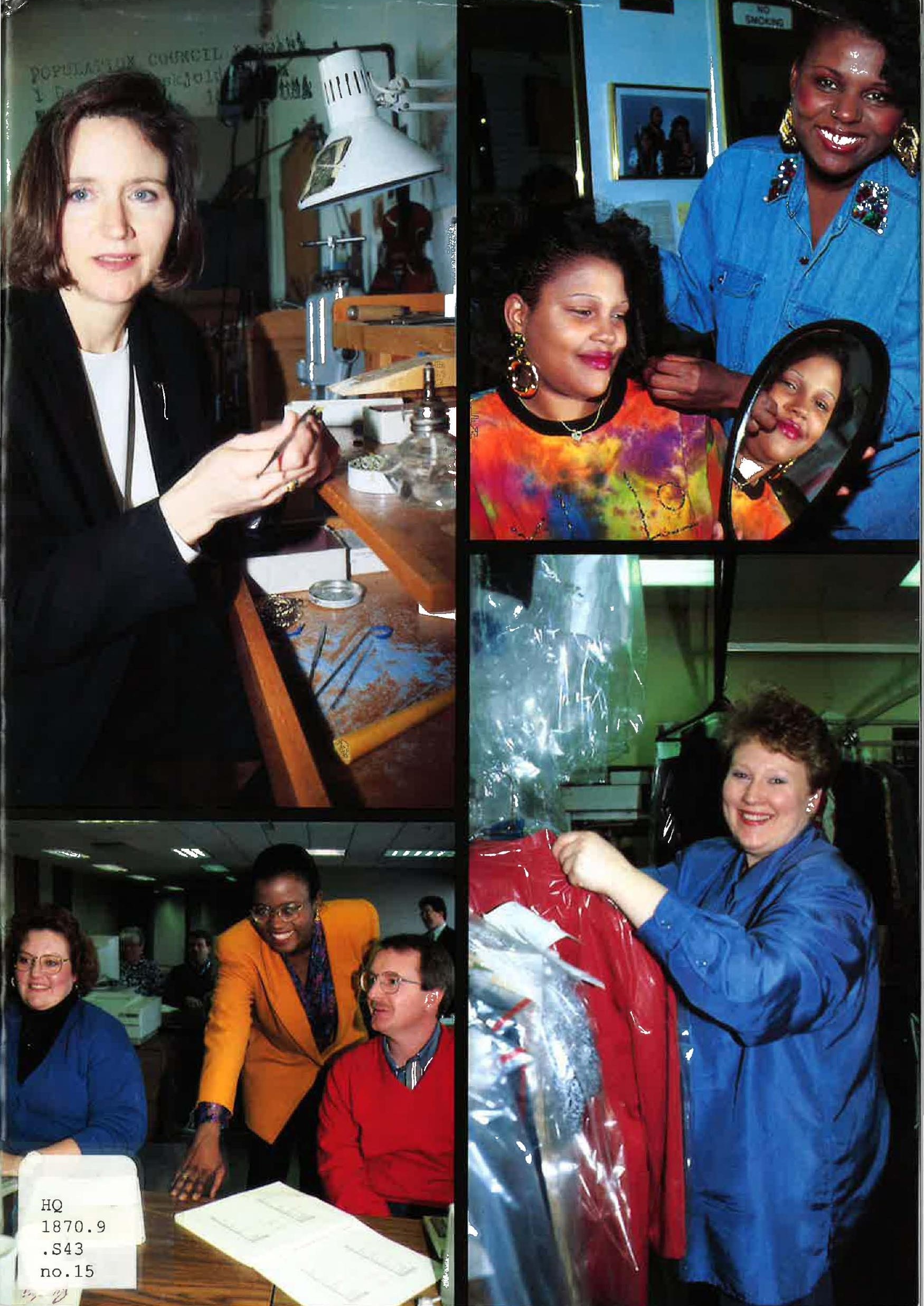

19

arm- in 
SEEDS is a pamphlet series developed to meet requests from all over the world for information about innovative and practical program ideas developed to address the economic roles and needs of low income women. The pamphlets are designed as a means to share information and spark new initiatives based on the positive experiences of projects that are working to help women generate livelihoods and to improve their economic status. The projects described in this and other issues of SEEDS have been selected because they have served not only to strengthen women's productive roles, but also to integrate women into various sectors of development, both social and economic. All projects documented in the SEEDS series involve women in decision-making, organize women locally, and address broader policy issues which affect the economic roles of women.

These reports are not meant to be prescriptive, since every development effort will face somewhat different problems and possibilities. Rather, they have been written to describe the history of an idea and its implementation in the hope that the lessons learned can be useful in a variety of settings. They are also being written to bring to the attention of those in decision-making positions the vital roles that women play not only in the economies of their individual households but also in the economic life of every nation.

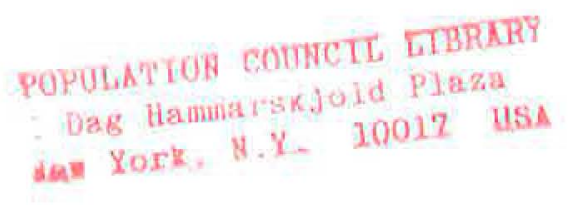

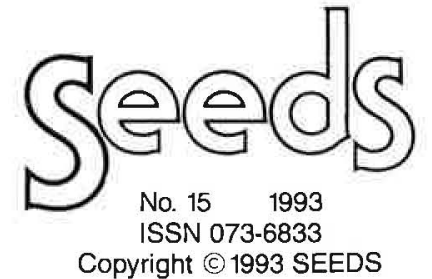

Copyright (c) 1993 SEEDS
The Population Council provides project direction and administrative support for SEEDS. Edilorial policy is set by the SEEDS Steering Committee: Judith Bruce (Populalion Council), Betsy Campbell (The Ford Foundalion), Marilyn Carr (UNIFEM), Marty Chen (Harvard Instilute for Inlernational Development) Margaret Clark (The Aspen Institute), Anne Kubisch (The Ford Foundalion), Ann Leonard (The Population Council), Cecilia Lotse (UNICEF), Katharine McKee (Center for Community Self-Help), Anne Walker (International Women's Tribune Center), and Mildred Warner (Cornell University).

Publication of SEEDS is made possible by support of the Ford Foundation, the Government of the Netherlands and the Population Council

Stalements made and views expressed in this publicalion are solely the responsibility of the authors and not of any organization providing support for SEEDS 


\title{
Self-Employment as a Means to Women's Economic Self-Sufficiency: WomenVenture's Business Development Program \\ Story by Katharine McKee, Sara Gould and Ann Leonard
}

\begin{abstract}
Introduction
While the "feminization of poverty" has been widely recognized as a global phenomenon in recent years, this term originated in the United States. For even though the U.S. remains one of the world's wealthiest nations, the number of its women and womenheaded households living in poverty is growing, mainly in the inner cities where fewer unskilled jobs remain. In rural communities, many factories have closed, family farming is declining and few other nonfarm options are available. Today these American women face many of the same obstacles that limit women's economic participation in all parts of the world.
\end{abstract}

\section{Women at Work}

The official rate of women's participation in the U.S. labor force has risen dramatically during this century, from 18 percent in 1900 to 57 percent in 1988. However, jobs in manufacturing, which traditionally provided the best-paying employment options for low-income, unskilled women, have decreased dramatically as many companies move their assembly lines to developing countries to take advantage of lower wages and less government regulation. Still other industries have relocated from urban settings to suburban areas where most low-income workers cannot afford to live.

Most of the new jobs that have opened up for women since 1980 are in service industries, such as retail sales and fast food vending, which pay at or slightly above the legal minimum wage. Therefore, it is not surprising that, despite the increased level of female economic participation, women in the United States still earn, on average, only two-thirds the income of men.

In addition, by 1982, 54 percent of all working women were mothers with children under 18 years of age. ${ }^{b}$ For many years the standard explanation for why women were paid less than men was that they tended to leave the labor force to have children, thus losing seniority and experience. However, recent studies suggest that when women find employment that offers a salary and opportunities similar to those offered to men, women are no more likely to quit work than their male counterparts. 


\section{Women in Poverty}

In 1987, 12 percent of all American families were living below what the government considers "the poverty line"1; but 34 percent of households headed by women were poor. ${ }^{c}$ In fact, the average "married couple" family (most with both husband and wife earning) had a median income more than twice as high as the average femaleheaded household. Of the women who headed 87 percent of all single-parent households by 1985, more than one-third of them were poor. ${ }^{d}$ For women belonging to certain minority racial groups, the situation was worse: While 16 percent of all women in the U.S. were poor in 1985, 13 percent of white women, 35 percent of AfricanAmerican women and 31 percent of HispanicAmerican women were living in poverty.

In addition to disparities in pay, one of the major causes of women's poverty is their disproportionate level of responsibility for children and other dependents. In fact, statistics show that when couples divorce, the woman's standard of living (and that of her children) often deteriorates drastically. Even in those cases where the courts mandate payment of monthly child support payments to the parent retaining custody of minor children (generally the woman) from the other wage-earning parent, as high as 40 percent of women awarded child support never receive any payments while an even larger number receive only partial or sporadic payments. Still others have no legal recourse to child support at all.

Lack of child care options is also a major constraint faced by working mothers. (Child care issues are discussed in length in SEEDS No. 13, 1991.) Poor quality child care facilities and the break down of extended family networks make this issue a constant concern. In addition, because many poor women are single mothers or divorced, they often face a sense of isolation; they do not have a support network to help them deal with the frequent crises they face or to give them a boost in their quest to better their lives.

A number of programs, funded by federal, state and local governments exist to assist families

\footnotetext{
"The "poverty line" is an index level, determined by the United States Government, that reflects the consumption needs of families depending on their size. In 1990, a family of three living on an income of U.S. $\$ 10,419$ or less was considered to be living in poverty. The poverty line is defined by a comparison of total annual household income, before taxes, with the cost of basic commodities and services (e.g. food and rent). Each year the rate is adjusted for inflation.
}

living in poverty. These include unemployment insurance, social security benefits for children, food stamps, health services and monthly stipends to help with rent and other expenses. These public transfers of income and services are often referred to as "welfare" or "public assistance." For many poor women, these economic transfers fill the gaps between unstable employment and often serve as the major source of support for their family. Yet, in recent years, the actual value of these economic transfers has been steadily decreasing due to inflation and cuts in government programs, while the costs of housing and health care continue to spiral upward. In addition, programs such as unemployment insurance and social security tend to favor men since these programs are based on the amount of wages earned and men not only earn higher salaries but also tend to be employed for longer consecutive periods of time.

So while welfare programs may prevent starvation, they do not necessarily alleviate hunger as money often runs out well before the arrival of next month's welfare check. And programs such as Aid to Families with Dependent Children (AFDC), the largest source of public assistance in the U.S., themselves present obstacles that prevent women from bettering their lives. Regulations governing eligibility - to receive not only income but also access to health care and other servicesseverely limit the assets a family can possess without losing all welfare benefits. The assumption is that people will leave welfare for full-time wage employment and will not need further assistance. There is no provision in the system for a gradual or partial transition off of public assistance through part-time or self-employment. These regulations, therefore, drastically reduce the ability of poor women to make the difficult climb out of poverty to self-sufficiency. And while for most families reliance on welfare is a temporary measure, for a small segment of America's poor, the current welfare regulations have contributed to a growing cycle of poverty in which second and even third generations of women are raising families on public assistance.

\section{Self-Employment and Low-Income Women}

In the early 1980s, it became evident that new solutions were required to meet the needs of the increasing number of people, particularly women and children, living in poverty in the 
United States. One option that generated a lot of interest was self-employment, particularly microenterprise development. Small businesses have always been an important source of employment. Between 1980 and 1986 (a period of economic recession), the number of women-owned small sole proprietorships in the U.S. skyrocketed, increasing by 62.5 percent to a total of 4.1 million businesses.'

Experience over the last decade has shown that for some poor women, self-employment can offer the means to become self-supporting and to gain increased self-esteem, provided they are offered assistance that includes development of business skills, access to credit and other support services. However, it is important to keep in mind that small business development remains largely a high risk, labor intensive activity that often, at least initially, must be combined with a low-wage job in order for a family to make ends meet. It should, therefore, be viewed as an option suitable for some people, but not as a substitute for the development of wage employment for the majority of low-income people.

In the United States today there are a growing number of programs that have been devel- oped to assist low-income women become self-employed. One of the pioneering efforts that has served as a model for many other programs throughout the United States and beyond, was the Women's Economic Development Corporation (WEDCO) in St. Paul, Minnesota, the first microenterprise development program to provide services directly to low-income women. Over the years, as it sought to respond to the broader employment needs of women, WEDCO expanded it services. In 1989, WEDCO merged with an employment counseling program and subsequently the organization changed its name to WomenVenture to reflect its expanded range of services. Today, the "WEDCO" component of WomenVenture is referred to as its "business development program."

This issue of SEEDS focuses on the evolution of WomenVenture's business development program (the name WEDCO is sometimes used in the text where historically appropriate). This model, which has provided a way of helping women start businesses and become self-sufficient without incurring overwhelming risks, continues to be an example of interest to other organizations seeking to help women become self-employed.

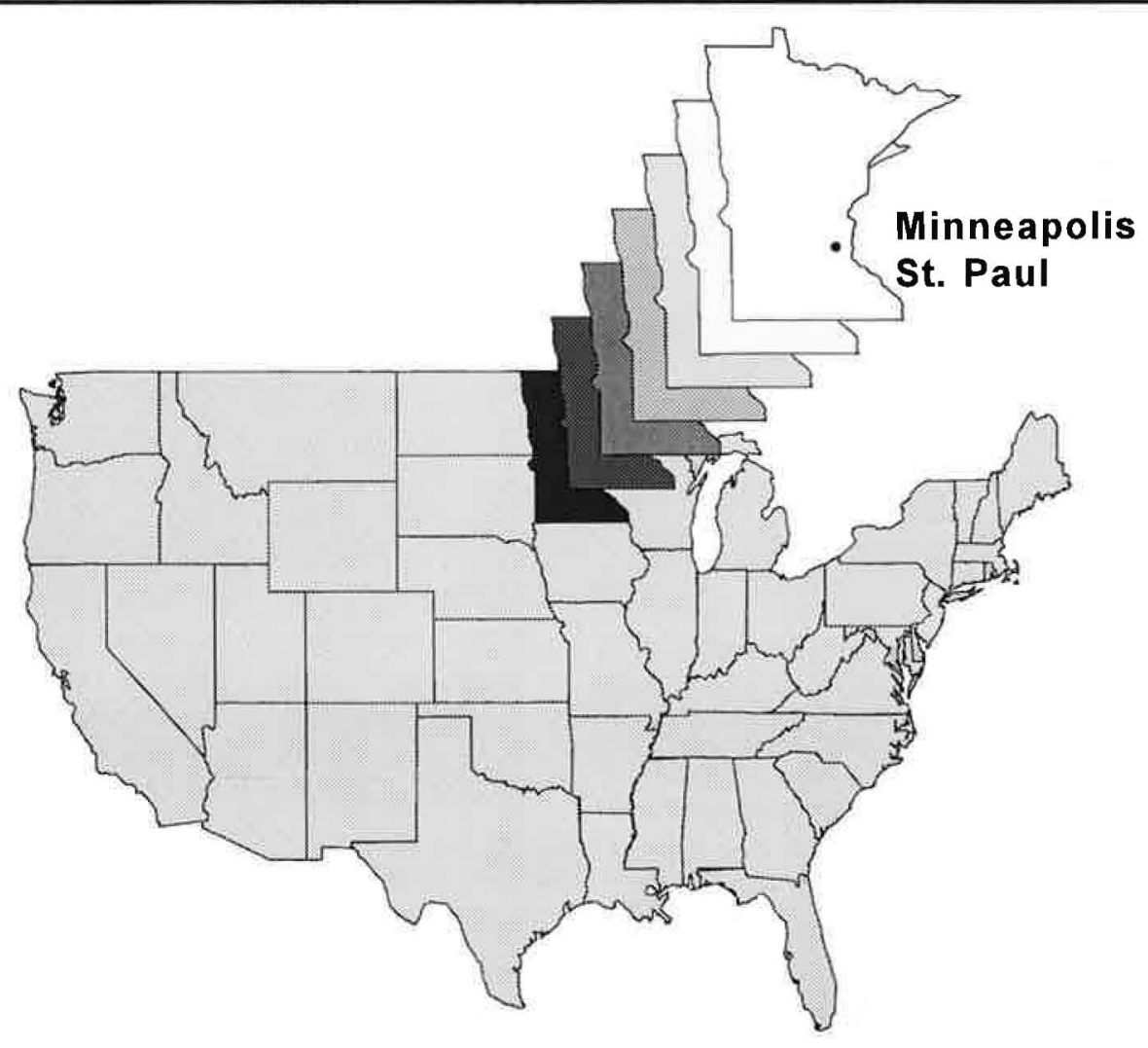


Wanda is a single parent with a three-year old child. She was referred to WEDCONV by a local bank after she had accused the bank of sex discrimination when they denied her request for a loan to buy a truck. Wanda wanted to start a business to haul trash and rubbish from construction sites. She had walked into the business loan department of the bank with a toddler and no business plan. When Wanda came to WEDCO/ $W V$, she was given assistance in developing a business plan and cash flow projections. Armed with these documents and new knowledge, Wanda was able to lease two trucks and establish herself as a minority contractor ${ }^{2}$ for the city. In addition, she has started a small tool rental business out of her house.

WomenVenture's business development program (formerly known as WEDCO) was created to help women like Wanda. Since 1984, more than 1,000 have been helped to start their own businesses, receiving loans in support of these microenterprises amounting to over three-quarters of a million dollars. An even greater number of women have been assisted in deciding NOT to go into business for themselves, but rather to gain needed education, skills and paid employment. WomenVenture (WV) is well aware that starting a very small business that can generate enough income to support a woman and her household is not easy for anyone. For women who are poor, the barriers are even greater. From the very beginning, it was recognized that if the WEDCO program was to reach and serve women like Wanda, it would have to be very different from traditional small business assistance programs in the United States.

\section{The Beginning}

In 1982, the United States was in the midst of a recession and the effects were beginning to be felt in the state of Minnesota. ${ }^{3}$ Jobs were becoming scarce, particularly in the industrial sector. In addition, for many women, available

\footnotetext{
In the U.S ${ }_{n, 2}$ federal, and some state and local governments, support development of minority-owned businesses (e.g. African-American, Hispanic-American, Native American) by giving them preference when bidding on various government contracts and services.
}

\footnotetext{
Minnesota is a large state located in the north central portion of the United States. The state capital, Minneapolis, is located directly across the river from its "twin" city, St. Paul. The urban population of the Twin Cities combined is approximately 2.5 million people.
}

employment options did not meet their needs not only for income, but for the flexibility needed to meet family care responsibilities or the sense of having some control over their lives.

So, in the fall of that year, two women concerned about the growing feminization of poverty in their home state decided to take a fresh look at ways to promote economic self-sufficiency for women. Working together, Kathryn S. Keeley, then Executive Director of Chrysalis, a women's counseling center in Minneapolis, and her colleague Arvonne Fraser of the Hubert Humphrey Institute at the University of Minnesota, were able to raise sufficient funds from local foundations to support a planning process to examine the causes of women's poverty and suggest program and policy initiatives to increase women's incomes and improve the quality of their lives.

The planning began late in the fall of 1982; by March 1983, a new area of economic opportunity for women had been identified: self-employment and small business development. To develop a program to help women take advantage of these new opportunities, an advisory group was formed made up of at least 60 women and men in the Minneapolis-St. Paul area. They participated in several task forces that looked at: the language of economic development and entrepreneurship and ways to make it less intimidating to women, particularly low-income women; the kinds of day care, housing, income maintenance and other services women would need to make the transition to self-employment; and the types of training and financial assistance required to meet the needs of low-income women. In addition, Chrysalis carried out a survey of 300 predominantly low-income women interested in microenterprise development. They identified lack of financing-particularly small loans (amounts from $\$ 500-\$ 10,000$ ) - as a primary need.

It was at about this time that Barbara Allivato, then Vice President for Urban Development at the Minneapolis-based First Bank System, happened to see Kathy Keeley on television describing the preliminary findings of the planning process. Keeley's enthusiasm and credibility sparked Allivato's imagination. She recognized that women business owners represented a unique opportunity for her bank.

At this point, events began to move quickly. In September 1983, the advisory group in the Twin Cities recommended the formation of a new organization, the Women's Economic Development Corporation (WEDCO). Kathy Keeley was named 


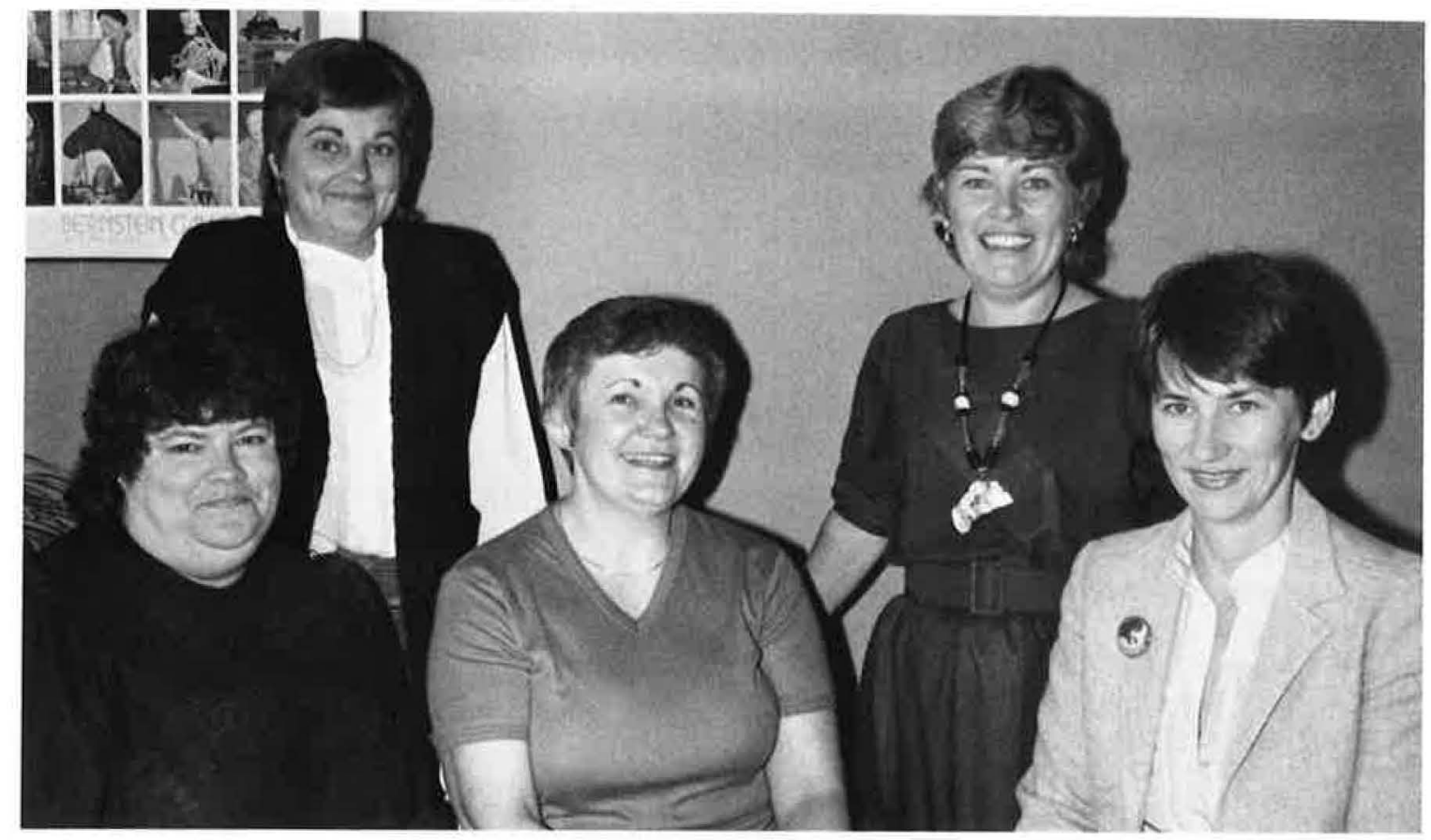

Executive Director. WEDCO opened its doors to clients in January 1984. Initial financial support came from three private foundations, but soon expanded to include corporate support and eventually funding from the State of Minnesota.

With the resource base taking shape, Kathy Keeley began to build a staff. In addition to Keeley, initial staff included an administrative assistant and a second professional person who began the intake and assessment work with WEDCO's first clients. Within three months, the need for additional expertise in both marketing and finance was clear but resources could fund only one position. Keeley devised a creative solution; she created two part-time jobs and filled the positions with women who were business owners themselves and wanted to remain engaged in their own enterprises.

The new organization set out to achieve three main goals:

- To increase the economic self-sufficiency of women through self-employment

- To improve women's access to financial resources

- To act as a catalyst in linking women with emerging business opportunities

As the staff began working with clients, these goals took shape and gained greater clarity. Because the term "economic self-sufficiency" is a vague one, staff engaged in discussions about what they meant when they used it. They reached general agreement that economic self-sufficiency for a woman meant that she was able to earn enough income to support herself and her family. In fact WomenVenture chooses to emphasize the word "self-employment" rather than "business" in their initial discussions with clients because they have found that while most potential women entrepreneurs can see themselves as becoming "self-employed," initially they cannot visualize themselves as owning and operating a business -the concept implies something too big

From the onset, it was realized that one of the most important services they could provide was to help women gain access to financial resources. This meant opening two different doors: 1) pursuing creative partnerships with conventional lenders who could assist some women, and 2) establishing an in-house loan fund to provide first-time credit for women considered "bad risks" by banks.

Finally, staff decided that the most effective way to link women with emerging business opportunities was to make those opportunities visible. This involved highlighting recent advances made by women and bringing them to life by featuring the experiences of real women as role models as well as bringing greater visibility to women operating nontraditional businesses. 


\section{The Business Development Program}

Beverly is a Native American ${ }^{4}$ woman about 50 years old. She came to WEDCONV after a bank in St. Paul turned down her request for a loan to start her own pest control business to support herself, her husband and two children. Beverly needed to borrow $\$ 3,500$ to buy equipment and to obtain the necessary insurance and licenses. The bank denied her request due to a lack of collateral: she owns no property because lands belonging to Native Americans are communal and are held in trust by the U.S. Bureau of Indian Affairs. With help from WEDCOMV. Beverly completed a two-page business plan and set out to visit Native American reservations in Minnesota, North Dakota, South Dakota and Nebraska to bid on pest control accounts for tribal buildings, schools and Native American health service offices. When she returned, she had $\$ 22,000$ in signed contracts-more than enough collateral to secure a WEDCONV loan. In addition, she was able to register as a minority contractor to get work with public housing projects and other public sector businesses. The business is now providing Beverly and her family with steady employment and a good income.

WomenVenture's clients face all the problems typical of most start-up enterprises-limited business and management experience, lack of adequate financing, need to build a customer base from scratch. However, as women they confront other obstacles: barriers of isolation, lack of self-confidence, heavy family responsibilities, lack of formal business training, very limited money of their own to invest in their enterprise and, all too often, sex discrimination by bankers, customers and suppliers. Furthermore, many women do not get much encouragement from their family, husbands or partners in trying to achieve self-sufficiency through creating their own businesses.

To tackle all these barriers to self-employment, a very comprehensive assistance program was designed. The components include:

- Training in business planning and management

- One-on-one consulting tailored to each client and her business idea

\footnotetext{
4"Native American" refers to the descendants of the native people populating North America before the arrival of European settlers. Many Native Americans live on tribal lands, called reservations, held in trust by the U.S. Bureau of Indian Atfairs.
}

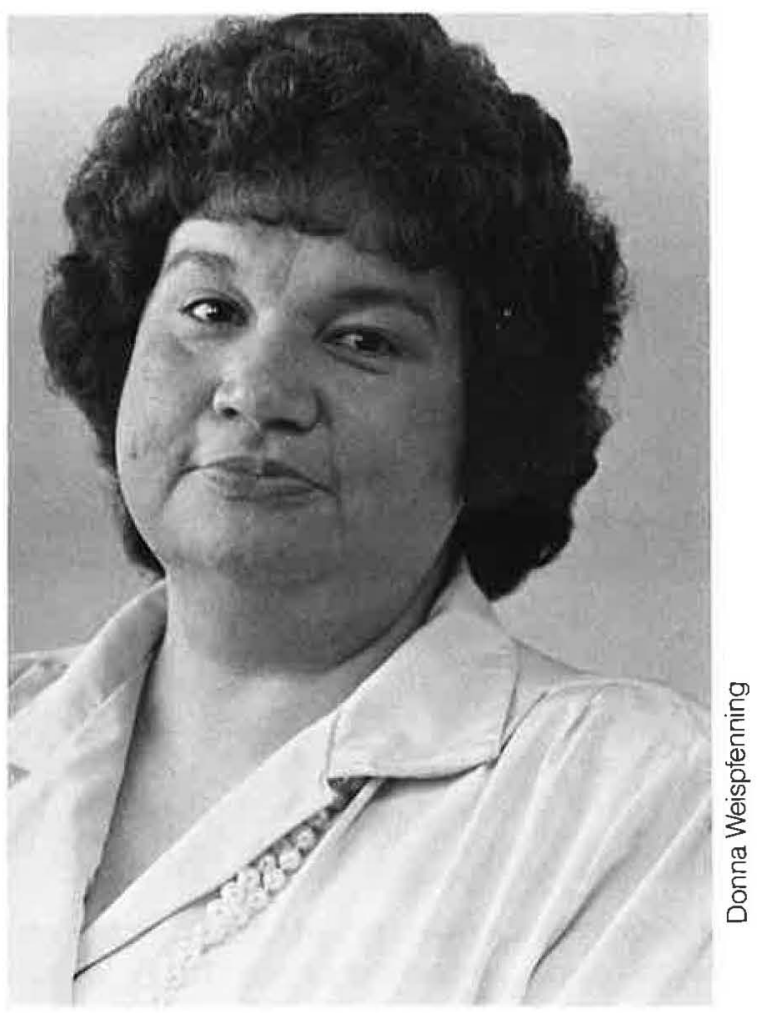

- Exercises to build self-esteem and personal effectiveness

- Financial packaging and loans

Thus, WomenVenture provides encouragement and social support for clients' income-earning efforts as well as business skills and services.

The program also offers follow-up assistance to help clients with the production, marketing, cash flow and personal problems that arise once they have launched their self-employment enterprises. Another important role that WomenVenture plays is to provide a place where clients can come to discuss the challenges they face with business professionals and other clients.

\section{How the Process Works: Self-Screening and a Step-by-Step Approach}

To better understand the business development process, we will follow a typical client through the initial phases of the program. Erica is a single parent with two children. Before coming to WomenVenture, she had worked at a variety of low-paying jobs (factory assembly line, hospital aide, clerical work). For several years she had been making jewelry at home for her family and friends; people frequently suggested that she ought to go into business. So, when Erica came to 
WomenVenture, she already had an idea of what she wanted to do.

Erica heard about WomenVenture through friends and went to one of their regular orientation sessions ("Considering a Business"), to learn more about the rigors of starting a business. About 12 women were there (approximately 500 attend these sessions each year). Some already had small businesses or part-time, home-based selfemployment activities. Many, like Erica, had a specific business idea and had come to see whether WomenVenture could help them turn their dream into reality.

At the orientation sessions, staff give potential clients an overview of the risks and opportunities, successes and failures, frustrations and rewards of self-employment. Again and again they emphasize that owning and operating a business is not for everyone and requires many skills as well as long hours of planning and hard work. On average, less than half of the women who attend an orientation session continue in the program. But Erica was determined. She signed up for the next step in the process, an individual interview with a staff person, referred to as a "business consultant." Typically WomenVenture consultants have themselves started and run at least one small business or self-employment venture. Many continue to do so while serving on the staff.
At a potential client's first interview, she presents her business idea, plan or problem to a WomenVenture consultant. As she describes her plans, the consultant takes notes and asks many questions. She then goes over a detailed outline describing the different services and assistance that WomenVenture can provide if the applicant chooses to become a client. The consultant explains that in addition to providing training, technical assistance and advice to her as she prepares her business plan, WomenVenture can also help her obtain the financing needed to start up her venture, either from a bank or from its own loan fund.

The consultant also explains that as a client she will need to agree to carry out a series of specific tasks - referred to as "homework" - that make up the business planning process, if she wants to move on to the next stage and continue receiving advice and services. If she agrees, she and the consultant will decide how much she will have to pay for each service. WomenVenture offers its services on a sliding fee basis, depending on the woman's income; fees range from as low as $\$ 20$ up to $\$ 60$ per consultation.

WomenVenture's leadership believes that they must be "businesslike" with their clients, just as their program trains clients to be businesslike with customers and suppliers. Paying a fee for

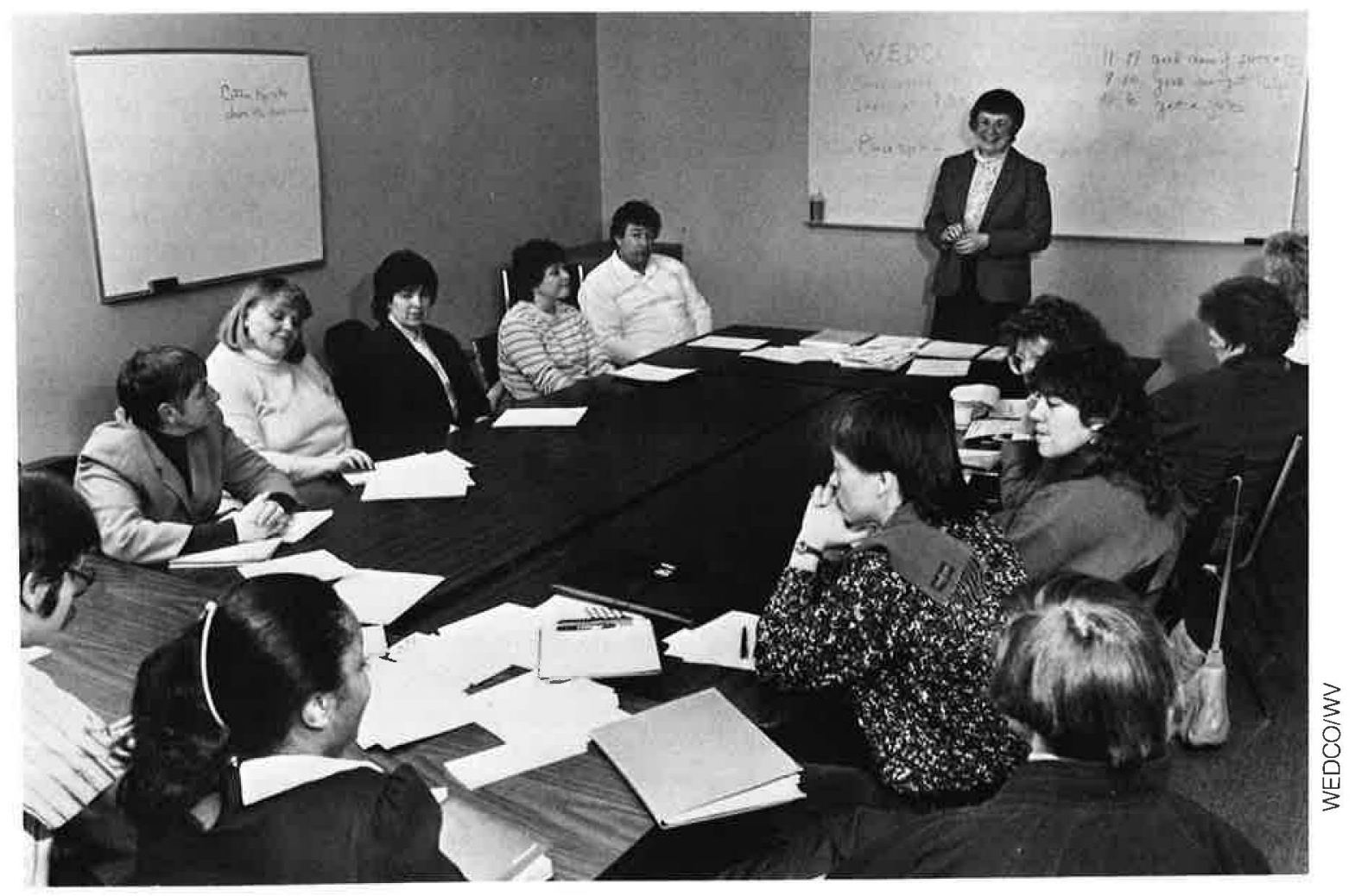




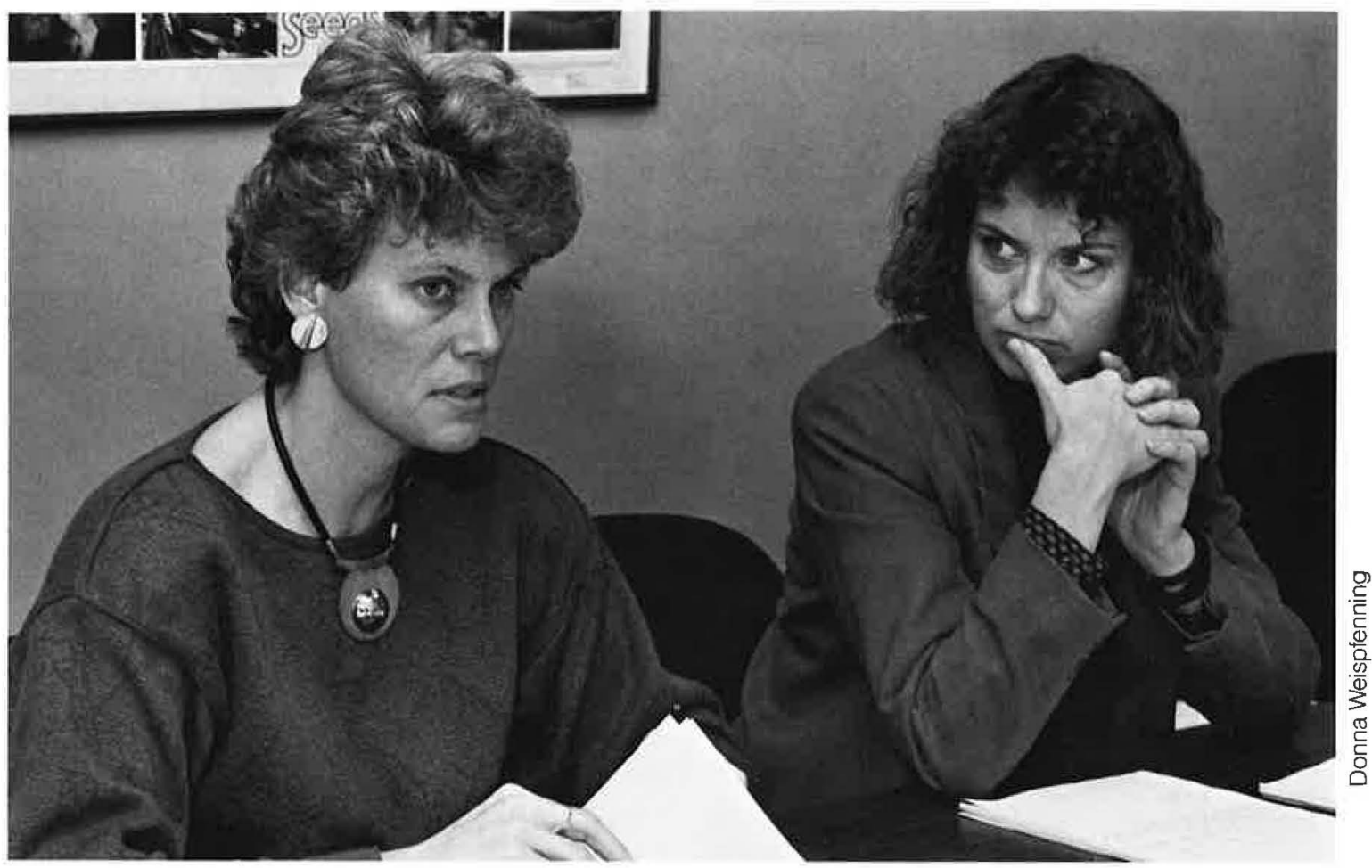

classes and consultations will encourage women like Erica to think hard about whether the services are valuable and whether they are prepared to move on to the next stage.

At this point, many clients are uncertain whether they want to proceed and about one-half drop out, but Erica is ready to begin. She signs an agreement setting out the roles and responsibilities that she and WomenVenture will each assume. The next step for her is to attend a training session or workshop that will get her started on the step-by-step business planning process. After that, she will meet with her consultant as she completes each section of "homework."

This illustrates another basic principle of the WomenVenture business development modelthe business planning process is broken down into many different steps so that clients will not feel overwhelmed and will be able to acquire skills and knowledge at their own pace. The building blocks of the training and assistance program are a series of worksheets covering the different components of starting a business: deciding which product to make or service to provide, determining who will buy from you and how much they will be willing to pay, analyzing your competitors, figuring out what equipment and supplies you will need to purchase or lease and where to get them on the most favorable terms, preparing your home for the business or identifying a suitable location, and so on.
Each client must complete one worksheet before moving on to the next. She may decide not to continue at any point. WomenVenture believes that the business development process should be self-paced, with the client deciding how quickly to plan, start up and expand her business.

Classroom training and individual meetings with consultants help clients complete each step. Typically, a client will attend six to ten consultations or classes over a two to eight-month period to complete her business plan. At times WomenVenture has also developed work groups to give clients a chance to work closely with other women on learning specific skills and solving problems. Work groups in marketing, selling, record keeping, pricing, dealing with personal problems, or financing, for example, provide clients with indepth training and opportunities to fine-tune their business ideas while getting feedback and support from other women.

A very important component of the WomenVenture planning process is identifying the client's income needs and the business's financing needs. Consultants help each client figure out a two-year budget that covers her basic needs and those of her family, including expenses such as child care that are often overlooked by traditional business planners. With staft help, each client also estimates the expenses, revenues and net profits that her venture can expect to accrue during its first two years of operation. Then comes the 
moment of truth-will the business or self-employment activity produce enough money for the client to be able to support herself and her family? If not, it is back to the drawing board. Approximately one-half of clients have to restructure their plans at this point. The consultants try to help them figure out how to reduce expenses and increase revenues so that their business idea can be viable.

Joanne wanted to start a seamstress business that would be located in a fabric store chain. WEDCONV assisted her to develop a business plan and identity her market. She then requested a very large loan from WEDCONW, which was denied because the debt service required would overextend the business. It was suggested that she rethink her plan-starting somewhat smaller and planning to grow more slowly, without assuming a large debt. In the end, Joanne was able to start her business with $\$ 4,000$ in capital, and now feels that this was the most helpful turndown she ever received from a funding source.

Sometimes at this point, despite all the work put in to her self-employment plan, a client is forced to conclude that her business idea will not work. WomenVenture staff feel strongly that one of their most important roles is to help women decide not to become self-employed, if this would worsen their economic and/or personal situation. In fact, WEDCO founder Kathy Keeley strongly emphasizes that self-employment is not for everyone. "Self-employment is," she stresses, "only one means to women's self-sufficiency."

\section{Getting Financing - The "Stepping Process"}

If the client's plan appears viable, the stepby-step planning process helps her to assemble the information she needs to apply for a loan from a bank or from WomenVenture. Not all clients need to borrow money to start or expand their businesses. Some are able to pull together money from savings or from family and friends, but since many participants are low-income and have little savings, financial packaging is an essential part of the WomenVenture model. After Erica completed all the sections of her business plan, the consultant helped her to prepare a written loan application.

\section{Bank Financing}

Whenever possible, WomenVenture encourages clients to apply for a bank loan, since a long- term goal is to make traditional financial institutions more responsive to the credit needs of women's businesses. After Barbara Allivato learned about the program and got involved, WEDCO developed a particularly close working relationship with First Bank. In the program's first four years, with funds provided by First Bank and others, 120 loans and guarantees were made to WEDCO clients, ranging from $\$ 50$ to $\$ 125,000$, for business start-ups and expansions.

Yet building partnerships with banks has not been easy. Most bankers continue to view WomenVenture's clients as high-risk borrowers because most have no previous business experience and few personal or business assets. In addition, bankers usually are not familiar with the types of self-employment activities the women want to carry out. With each new loan officer, another education process is required to explain the program's goals and methods and present its strong track record.

Perhaps the most important constraint is that it is not profitable for a bank to make such small loans because the transaction costs are almost the same as they are for large loans and, because more individual borrowers are involved, small loans are more expensive to administer. Very few commercial banks will even consider making a business loan under $\$ 10,000$; some will not accept applications under $\$ 50,000$. At First Bank, the WomenVenture-referred loans were all granted from the bank's personal loan division rather than its business loan division. While this permitted the bank to make smaller and more flexible loans, it also made it more difficult for clients to benefit from an experienced business lender's advice and to build up a track record as a business borrower.

\section{WomenVenture Financing}

Because most of its clients' needs cannot be met through partnerships with banks, it was recognized from the outset that it would be necessary for WomenVenture to capitalize its own loan fund by raising money from foundations and corporations. Several different approaches to lending have been tried to date. Originally, two funds were created; one to guarantee bank loans and another to make direct loans and investments. This division, however, did not prove workable so the money was combined into one fund. As of the end of 1991, The Seed Capital Fund had $\$ 307,000$ in assets and made loans ranging from $\$ 30$ to $\$ 28,000$. WomenVenture is currently initiating a new lending program with funding provided by 
the U.S. Small Business Administration (SBA). These SBA funds will be used to finance nontraditional enterprises of low-income women, and men, up to a maximum of $\$ 25,000$. Clients make applications to the loan funds the same way they apply to a bank.

The lending program embodies several WomenVenture principles. First, it is designed to be a "stepping process" for clients. Stepping loans start out small-just enough to allow the entrepreneur to test her business idea, make repayment and build up her business without incurring unreasonable debt. For example, a client is often given a very small loan that is just enough to allow her to purchase some inventory, print some brochures or business cards, etc. WomenVenture then asks the woman to go out and try to sell her service or product, committing to finance 50 percent of any sales or services she generates, thus insuring that she can deliver her orders.

This process provides the woman with an incentive to try her business idea while at the same time minimizing risk to the loan fund, as repayment is tied directly to sales. Once the woman demonstrates that she can get clients and deliver her orders, she becomes eligible for progressively larger loans. In this way her business can grow gradually as she is learning and practicing new management and marketing skills. At the same time, she is building a track record as a borrower. As soon as possible, she is encouraged to "graduate" to a bank loan, so that WomenVenture's limited loan funds can be made available to other clients.

A second guiding principle is that financing should be flexible, tailored to the specific financing needs of the client's particular business or selfemployment activity. Each client is responsible for negotiating the duration, interest rate, pace of repayment (tailored to her business' cash flow) and other terms of her loan with the loan committee. Interest rates are at or near market rates as WomenVenture does not believe in subsidizing women's businesses. They treat their borrowers as business owners, just as a bank would, so that the women understand that this is not a giveaway program but serious business in a real world context.

Third, every client must pledge some type of collateral for her loan, even if it consists of property a bank would not typically accept as security: flowers, plastic, cleaning supplies, pianos-even very old cars. Also accepted are signed sales contracts to deliver goods or services to customers or other "intangibles." WomenVenture then files liens (charges upon real or personal property for the satisfaction of a debt) with the State of Minnesota on this collateral so that their clients see that this is legally a business loan. This is a very important step in the process not only because insistence on collateral helps to ensure that the clients feel a strong commitment to repay and that they understand the risks involved in self-employment, but because it helps clients build credit histories that they can later present to banks.

Leslie had experience working as a florist but had failed at starting her own floral business. Upon analysis of her situation, WEDCOMV agreed to provide her with a $\$ 500$ loan to buy roses to sell for Valentine's Day (a U.S. holiday when flowers and candy are frequently given as gifts). She rented a store front for $\$ 200$ for one month and bartered with the local newspaper for an ad in exchange for roses for the office. She bought ladders and buckets to put the flowers in and hand painted a sign that offered a "love bunch" for \$8.99. Within five days, she was able to earn $\$ 3,000$ from the sale of the roses. She then repaid her loan and used the remaining funds to provide the capital she needed to start her business.

Three years later, WEDCONV made Leslie a second loan of $\$ 500$ for Mother's Day and again set a five-day term of repayment. She was able to generate enough cash to pay that loan in time and to buy her first cooler to keep her flowers. Leslie went on to borrow $\$ 70,000$ through a city program to purchase her own building and now operates from two locations. Today Leslie's business has sales of over $\$ 500,000$ annually. She owns three stores and two buildings and currently employs 15 other people. Not only is she supporting herself and her own family, but she is helping other women to do the same. She also served for a time as the president of the local merchants association.

Of course not all of WomenVenture's loans are so successful. During the first four years of the WEDCO program, when the loan fund was most active, the default rate ran at less than 20 percent. Clients whose loans appear to be "in trouble" are given special assistance in order to help stabilize their businesses, solve problems and pay off their loans.

But overall, WomenVenture's loan record looks good. Over the years, with about $\$ 900,000$ in loans to clients, their loss rate has averaged approximately four percent of outstanding principal in any given year. This compares favorably with other community development loan funds in the U.S. 


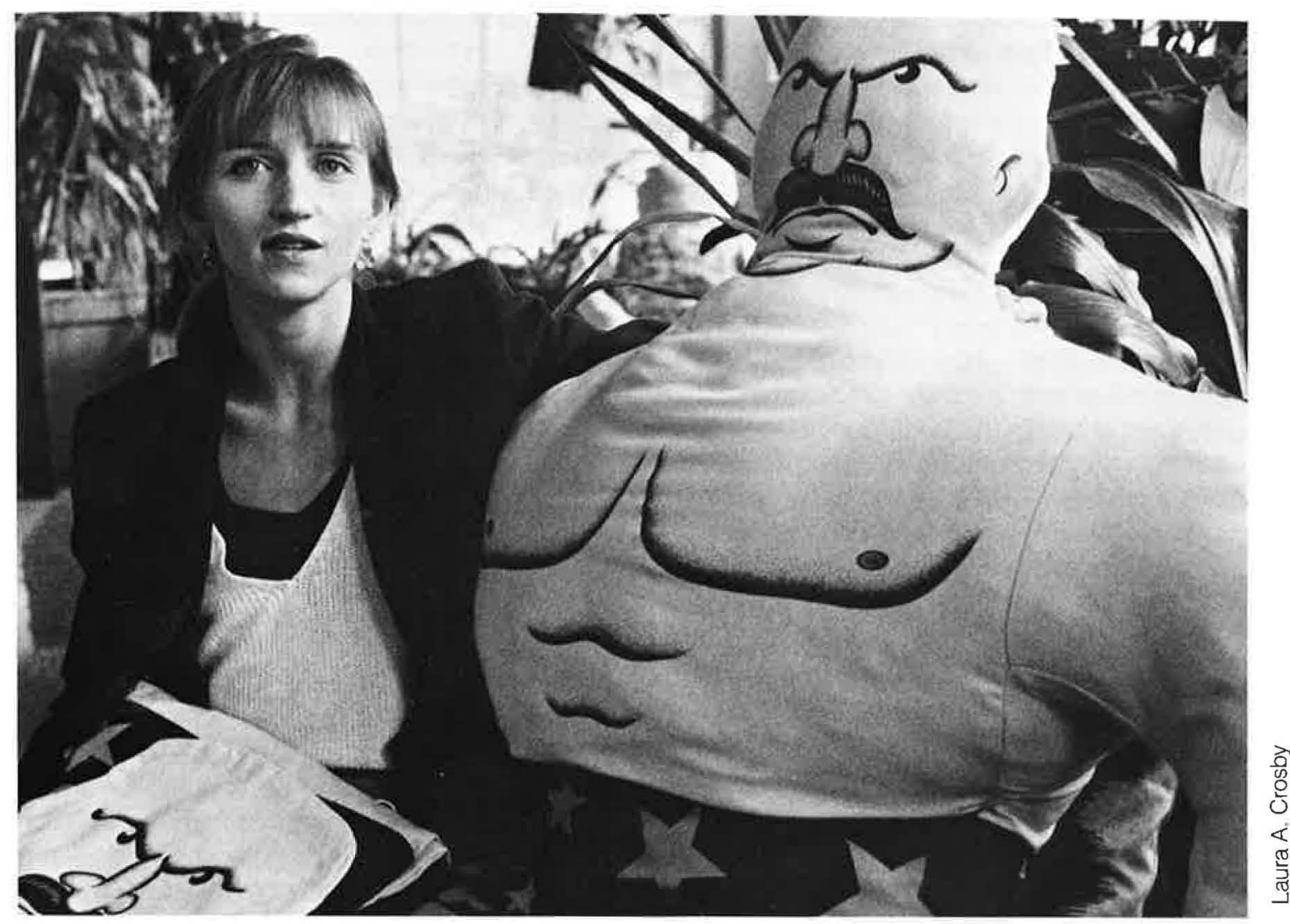

\section{Self-Employment Isn't for Everyone}

WomenVenture works on the principle of self-screening. Its staft do not believe that they can determine which business ideas will succeed and fail; rather, they help each individual client judge her venture's feasibility for herself and then decide whether she has the skills, abilities and determination to develop, market and finance a business. Women are allowed to "self-select"—to identify which business idea is right for them and to continually test their own readiness to operate a microenterprise successfully. By the end of this self-selection process, clients will have demonstrated to themselves, their families and WomenVenture that their proposed business is viable and that they are committed to carrying it out.

Many women screen themselves out after completing just part of the process. Upon further examination, a client may decide that her proposed business does not suit her needs after all, either because it cannot generate enough earnings or because it does not fit her current personal goals and circumstances, or because she cannot commit enough time and energy to make it work at this point in her life. She may decide to put off self-employment until family and day care responsibilities change. A number of women return to WomenVenture at a later date when they feel more secure about making a commitment.

\section{Building a Broader Base of Support for Working Women}

In the early WEDCO years, about five women per day would inquire about the business development program. Out of any five, approximately two would actually try to start their own businesses. The other three usually needed assistance in securing employment and skills training, education and support services to meet their economic needs.

To better assist these women, in 1989 WEDCO merged with CHART, a career and employment counseling program to create WomenVenture, an organization offering more comprehensive self-sufficiency services beyond business development. WomenVenture (WV) seeks to secure a stronger economic future for women through a focus on three areas: employment and career development, business development and financial responsibility. 
In addition to the business development program, WomenVenture has developed a Career Resource Center to meet the needs of the large number of women for whom self-employment is not the best option. To keep costs in line, this service recently was restructured as a self-help, self-paced program designed to give women access to a "tool box" of information and support systems as they make the transition to better jobs or new careers. A major component is The Exchange, a program that capitalizes on WV's extensive network of business professionals who consult with clients on a volunteer basis. Also included in the program is a job listing book, job search workshops, reference library and support group activities. The idea is to provide clients with an accessible, affordable and responsive mechanism to meet their particular needs.

WomenVenture's services are available to any woman, regardless of income. (Men sometimes inquire about WV programs, but only a few actually become clients.) Most WomenVenture clients are low- to middle-income women and a significant proportion are single mothers; many clients are women who, following a divorce, suddenly found their standard of living had plum-

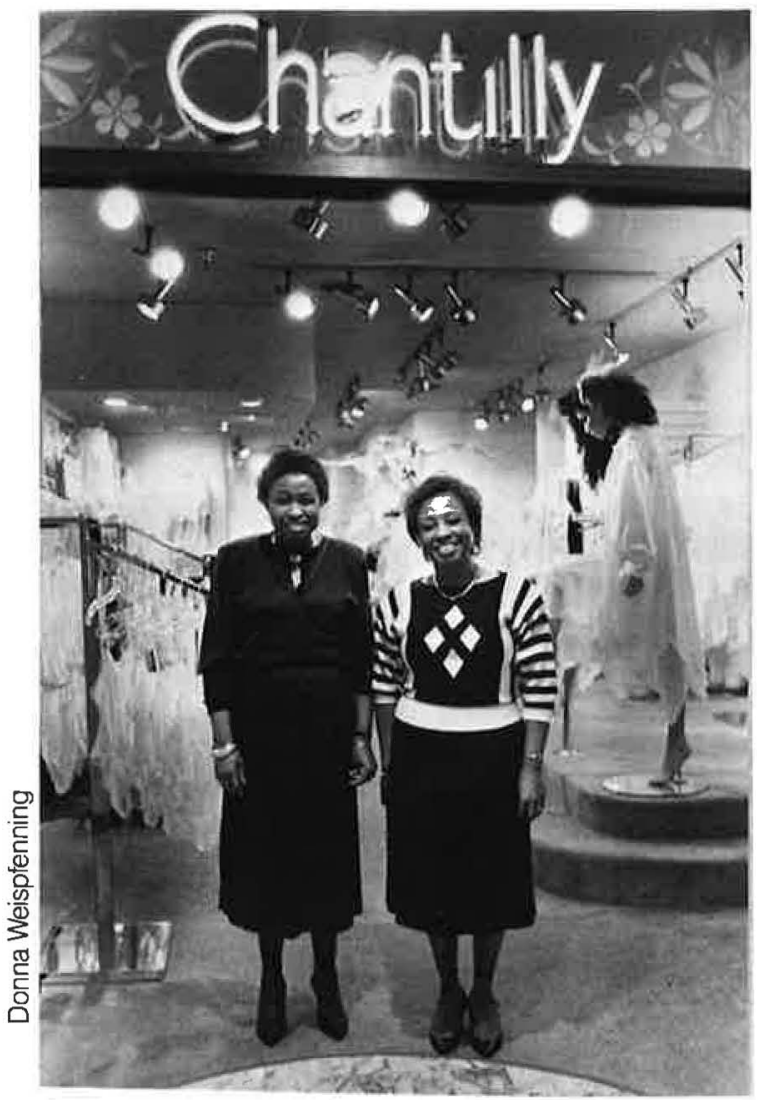

meted and were faced with being the primary or sole support of their family.

For most clients, the regular WomenVenture programs can meet their business and employment needs. But many women living below the poverty line face additional obstacles, especially women who are recipients of AFDC (Aid to Families with Dependent Children). To help these women on the road to self-sufficiency, special programs are necessary.

\section{The SETO Program}

In 1986, efforts began to design a program to provide business development services to women receiving public assistance. The SelfEmployment Training Opportunities (SETO) program is modeled on WomenVenture's regular business development program, but places greater emphasis on building women's self-confidence and teaching problem-solving and business-related skills. The training period for SETO clients is also longer, since most participants have little or no previous business experience and often limited formal education.

In addition to lacking money, education, experience and self-esteem, SETO clients face another major obstacle: they are receiving public assistance. AFDC not only provides poor families with cash income but also other benefits such as food stamps and access to health care. However, the eligibility requirements for recipients of AFDC severely restrict the amount of income or assets a family can accumulate and still receive benefits, thus actually discouraging people from trying to become self-sufficient.

Families on AFDC as a unit are not allowed to accrue more than $\$ 1,200$ in personal belongings, income, savings or assets (this does not, however, include the value of an automobile); nor are they allowed to separate business assets and income from their personal finances. At first WomenVenture tried to work around these restrictions by various means such as leasing equipment to clients and by paying vendors directly on behalf of SETO clients, but none of these were satisfactory. They therefore sought changes in these restrictive government regulations.

In 1988, WomenVenture became part of a national demonstration program initiated by the Corporation for Enterprise Development, a nonprofit advocacy organization with headquarters in Washington, D.C. This demonstration program, operated on a trial basis in five U.S. states, allowed 
AFDC recipients 12-month waivers from AFDC eligibility requirements while they attempted to make a gradual transition from public assistance to selfsufficiency. This meant that SETO participants had one year in which to build up equity in their businesses without suddenly losing all their AFDC health, food and income benefits.

Patricia Tototzintle, who managed the SETO program, describes the typical SETO client as follows:

In general SETO clients are single moms struggling to raise their children. Their monthly AFDC check does not cover all of their regular monthly expenses. The majority of our clients have no savings to fall back on, no real assets or property, no friends or close relatives able to provide financial support to a new business, and they are not considered good credit risks. As low income single parents, they are faced with daily barriers related to housing, food, clothing, transportation, child care and education. Low selfesteem is common among our clients as they enter the program.

From March 1988 through November 1991, 398 women attended SETO orientation sessions. Of these women, 229 enrolled in the training program and 188 completed the course. Sixty-eight new businesses have been launched, 23 with SETO loans. (SETO has its own financing program, making stepping loans from $\$ 500$ to $\$ 5,000$.) Fourteen of these businesses also include a partner or other employees. Seventeen of these new business owners have already made the transition off AFDC and are now able to support themselves and their families without the help of welfare benefits. Another 19 clients completed the training and then, using their new skills and self-confidence, were able to find regular employment; they are currently off AFDC as well. Thirtyone SETO clients chose to enroll in other education or training programs in order to pursue their employment goals.

Kim is 25 years old and has a seven-year-old child. She has been on AFDC for the last six years and wants to start a snow plowing business. She wanted to borrow $\$ 6,000$ to purchase a truck and plow. She planned to mow lawns in the spring and summer and to work part-time as a waitress to provide year-round employment. WEDCONV assisted Kim in completing her business plan and cash flow projections. It soon became clear that the snow plowing business could not generate enough income to support her and her daughter.
The lawn mowing business actually looked much more attractive when the financial projections had been completed. Therefore, Kim decided to postpone the snow plowing business and not go into debt or jeopardize her welfare benefits. Between mowing lawns and working part-time as a waitress during the spring and summer, Kim can save enough money to put a down payment on a truck and plow by next winter. She expects to be off welfare before the year ends.

The problems faced by SETO clients are similar to those of other WomenVenture clients, but usually they are intensified. Child care is an ongoing concern to most, as is transportation. In addition, many women face opposition from family members, particularly spouses or partners, who often attempt to undermine their determination to support themselves.

A SETO client had completed her cash flow projections and was in the final stages of planning her business. Her husband was unemployed. She came to Womenventure for her scheduled appointment wearing sunglasses to camouflage her black eyes and bruises. She said she had been sitting at her kitchen table working on her business plan when her husband, who had been drinking, flew into a rage, picked her up and slammed her down onto the floor. She said he had never done anything like this before. It was suggested that her decision to go into business might have something to do with his action. The client called a few days later to say that she and her partner had talked things out and everything seemed to be back to normal. However, the night before her next WV appointment he again flew into a rage and physically abused her. Thereafter, she decided not to mark her future appointments on her calendar and the beatings stopped.

A client's partner had been a drug addict for 16 years. He had harassed her every time she tried to work or go to school and did the same after she completed her SETO training. She filed a restraining order to protect herself and her children, but he continued to threaten her until he finally moved out of the state. That ordeal over, she learned that her 15-year-old daughter is pregnant.

Because SETO clients do have special needs, new approaches have been developed. A Research and Development (R\&D) track has been established for those who need more time and/or experience in developing their business ideas. R\&D clients work together in small groups where they receive ongoing support and critiques of their ideas as they move along. They also have 


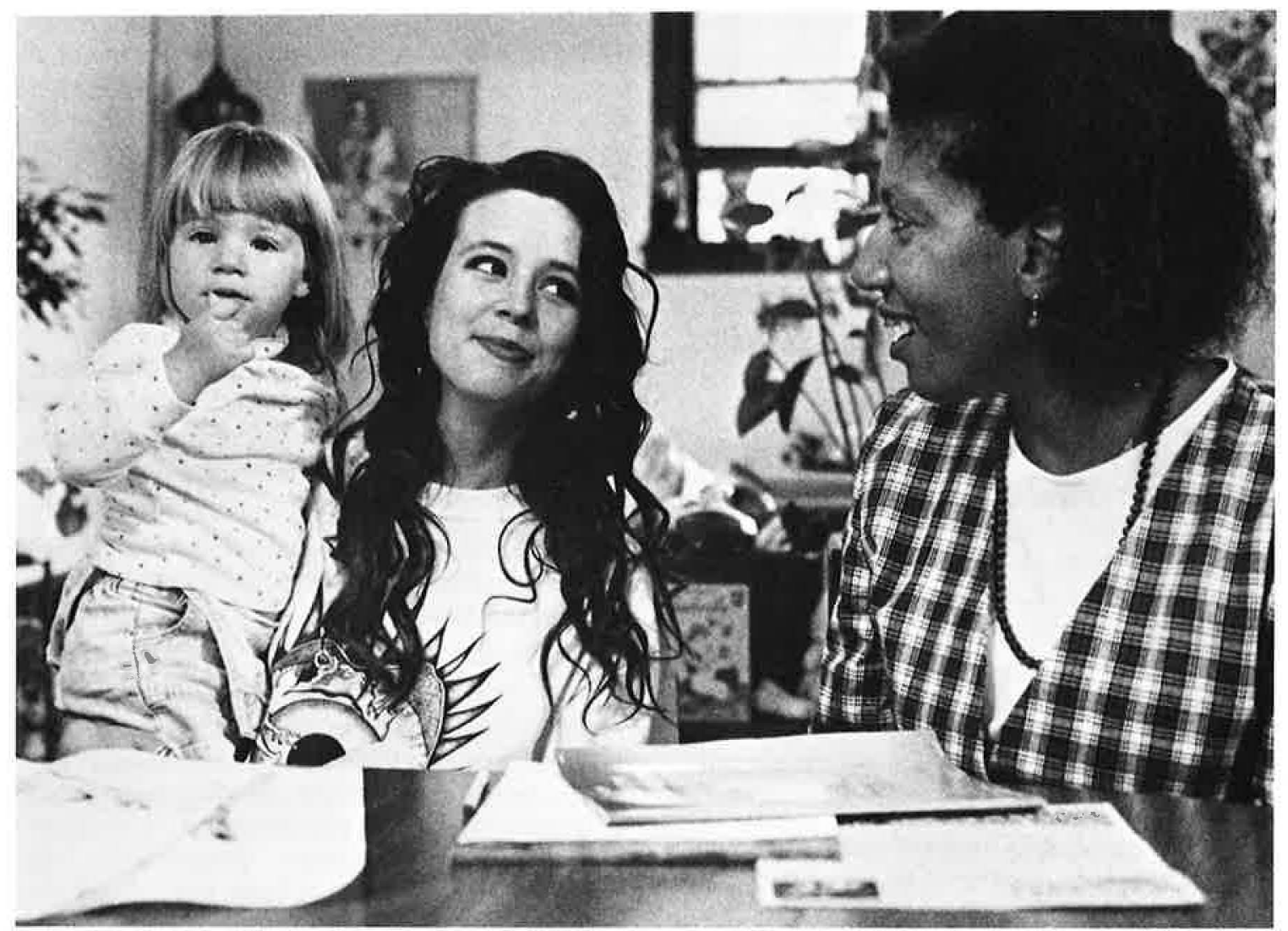

access to smaller "circle loans" of from $\$ 10$ to $\$ 100$ (called circle loans because loans are given to group members on a rotating basis). These loans allow clients to develop and test various prototypes before actually developing their business plan.

In 1990, a Business Law Clinic was formed, with the assistance of a local college. Law students, supervised by practicing attorneys working on a pro bono basis, provide free legal assistance to SETO clients that they could never afford on their own.

WomenVenture also offers SETO clients monthly support group meetings, help in handling social service related problems and followup assistance once their business is underway. The new staff position of "circuit rider" has recently been created to aid SETO clients at their place of work.

Stacey Millet joined Women Venture in 1989, just after the merger of WEDCO and CHART. She has a background in both journalism and business, having operated her own microenterprise as well as working in the corporate world. Initially Stacey was involved in marketing the career services programs and developing some of WV's educational materials. However, in October 1991, she took on the new assignment of "circuit rider," to provide onsite assistance to SETO clients. Once their business is in operation, many of these women experience a sense of isolation as they rarely have family members or friends who understand and can assist them in meeting their business needs. Stacey views one of her major roles as making the women aware that there is someone on call who understands and can help.

\section{Accomplishments To Date}

In 1984, when WEDCO began, its founders thought it might help about 25 new businesses get started. But since 1984, WomenVenture has assisted over 1,000 new businesses get underway in Minnesota and has provided training and consultation services to an average of 900 women per year. As of April 1990, over $\$ 886,000$ had been loaned to 81 women in the form of 92 direct loans and 15 guarantees to banks. Thirty-eight of these loans have been repaid in full; 13 have been written off.

While WomenVenture clients have started businesses in all industry sectors, they are concentrated in what are called "service" industries. A breakdown would be as follows: 


\section{Businesses of WomenVenture Clients}

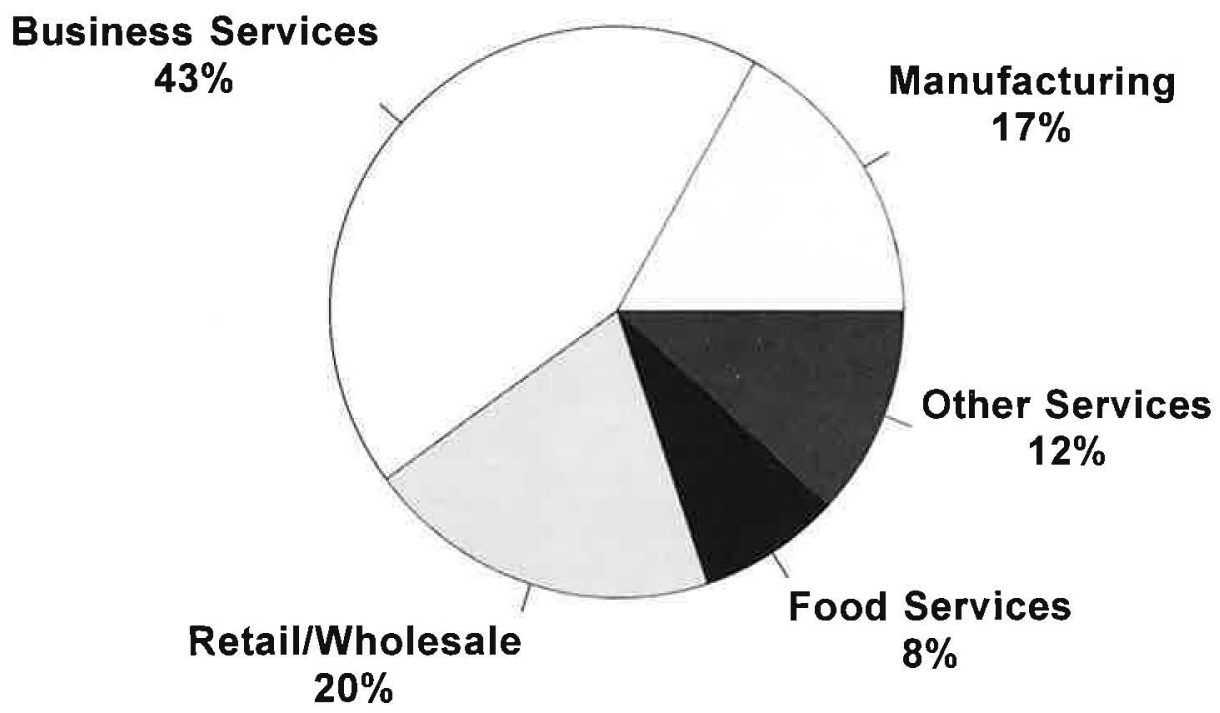

in addition to food service and retail sales, WomenVenture businesses include a medical transcription business, wholesale book distribution, temporary day care employment service, picture framing, tailoring, graphic arts, florist, monogramming and silkscreening.

A 1987 evaluation of the business development program included interviews with current and former clients. Respondents reported positive changes in terms of greater self-confidence, focus on and planning for life goals, taking charge of one's life and personal organization, which they attributed to their association with the program. Two-thirds of clients surveyed who now defined themselves as "moderately successful" and onequarter who now considered themselves "extremely successful," gave substantial credit to WEDCO for their improved situations. Clients defined personal success in various terms, including achieving balance and satisfaction in life, having financial stability and security, having satisfying and fulfilling work, setting and reaching goals, having a successful business, having a positive sense of self-worth and reaching one's potential, having healthy and supportive relationships.

Aside from the direct financing involved, the services valued most by clients were training, completing a business plan, loan packaging and doing financial projections.

\section{Broader Impacts and Future Challenges}

We believe that the program is about changing people's lives, removing barriers and giving them new economic tools. Long term, we believe that we are developing people who see themselves as having marketable skills, life choices and economic opportunities.

Kathy Keeley

A difficulty that will be faced by most successful programs is when the time comes to expand their services in order to meet greater demand for services and/or to respond to the more diverse needs of their clients. While the merger with $\mathrm{CHART}$, that resulted in the establishment of WomenVenture, seemed like a sensible approach to broadening WEDCO's ability to help women seeking self-sufficiency, the merging of two organizations with different operating styles, unique staffing dynamics and somewhat diverse clienteles, was not easy. New ways of managing programs, working with staff and clients, raising funds and the like were required. One reason the new name WomenVenture was adopted was to help create a sense of unity between the two programs. 
In addition, the success of the WEDCO model brought an ever-increasing amount of publicity and requests for information from individuals and organizations throughout the U.S, and beyond. While this attention created important opportunities to impact the field of mircoenterprise development more broadly, it also placed added stress on a small staff trying to run a service program with limited resources.

Another common transition organizations must face is when the founding members move on, as has happened with most of the core staff who established the business development program at WomenVenture. Keeley herself stepped down as president in early 1992, to work directly with the Corporation for Enterprise Development in Washington, D.C, seeking to design new welfare policies that invest in the economic development of low-income people. WomenVenture's new president, Kay Gudmestad, comes to the Twin Cities with a background in management of nonprofit organizations serving the needs of women and girls and in small business management. in her view:

The time has come for WomenVenture to undertake a comprehensive organizational development process that will complete the transition phase initiated by the merger and enable the organization to achieve a new level of quality in service delivery. Through the evaluation of impact of existing services and assessment of needs in this community, WomenVenture will position itself to build its leadership role in this community and continue to contribute to national thinking in small business development for women.

WomenVenture continues to evolve as it keeps pace with the needs of its clients and with the times. The organization has recently streamlined its operations, paring its operating budget down to $\$ 930,000$ for 1992 (from a high of $\$ 1.4$ million) and reducing the staff from 33 to 18 . One of the goals is to make greater use of volunteerslinking clients to the appropriate professionalsrather than having staff do all the work.

WomenVenture has also created several new approaches to help low-income women achieve self-sufficiency.

- Project Blueprint addresses the issue of occupational segregation by recruiting and training women for well-paying jobs in the male-dominated construction trades. It combines traditional career training skills with manual and physical training, job placement and personal effectiveness skills.

- Passport is a pilot program operating in two low-income communities in Minneapolis and one in St. Paul. It is designed to help community residents find a permanent job or become self-employed and to establish community businesses.

What about the issue of self-sufficiency? Fees from clients currently cover less than five percent of WomenVenture's operating budgetnot surprising given that in 1991, 58 percent of its clients had annual incomes of $\$ 15,000$ or less. WomenVenture, therefore, tries to seek as broad a funding base as possible, receiving support from a range of sources including foundations, corporations, individuals, state and federal governments and from contractual work.

WomenVenture continues to be a strong advocate for women's economic development not only locally, but also at the state and national levels. The organization has made good use of attention from the media, including being featured on 60 Minutes, currently rated as the most popular TV news program in the United States.

It was largely through WomenVenture's lobbying efforts that the demonstration program offering waivers to AFDC recipients was created; and WomenVenture continues to lobby for extension and expansion of such programs nationwide. The "WEDCO" business development model has also served as the inspiration for numerous women's economic development projects in other parts of the U.S. (some of these are profiled in the Appendix). Visitors from over 40 states and from foreign countries have come to the Twin Cities to study the business development model. WomenVenture also has produced a variety of manuals that both individuals and organizations can use in helping women establish and successfully operate small businesses.

\section{Lessons:}

1. Programs to assist low-income women become self-employed must provide their clients with three unique types of services. First, they must provide them with information, technical assistance and access to credit-the tools they need to successfully start and grow their businesses. Second, they must also provide women with special training and experiences that will help them build up their self-confidence and increase their sense of self-esteem so they can overcome 


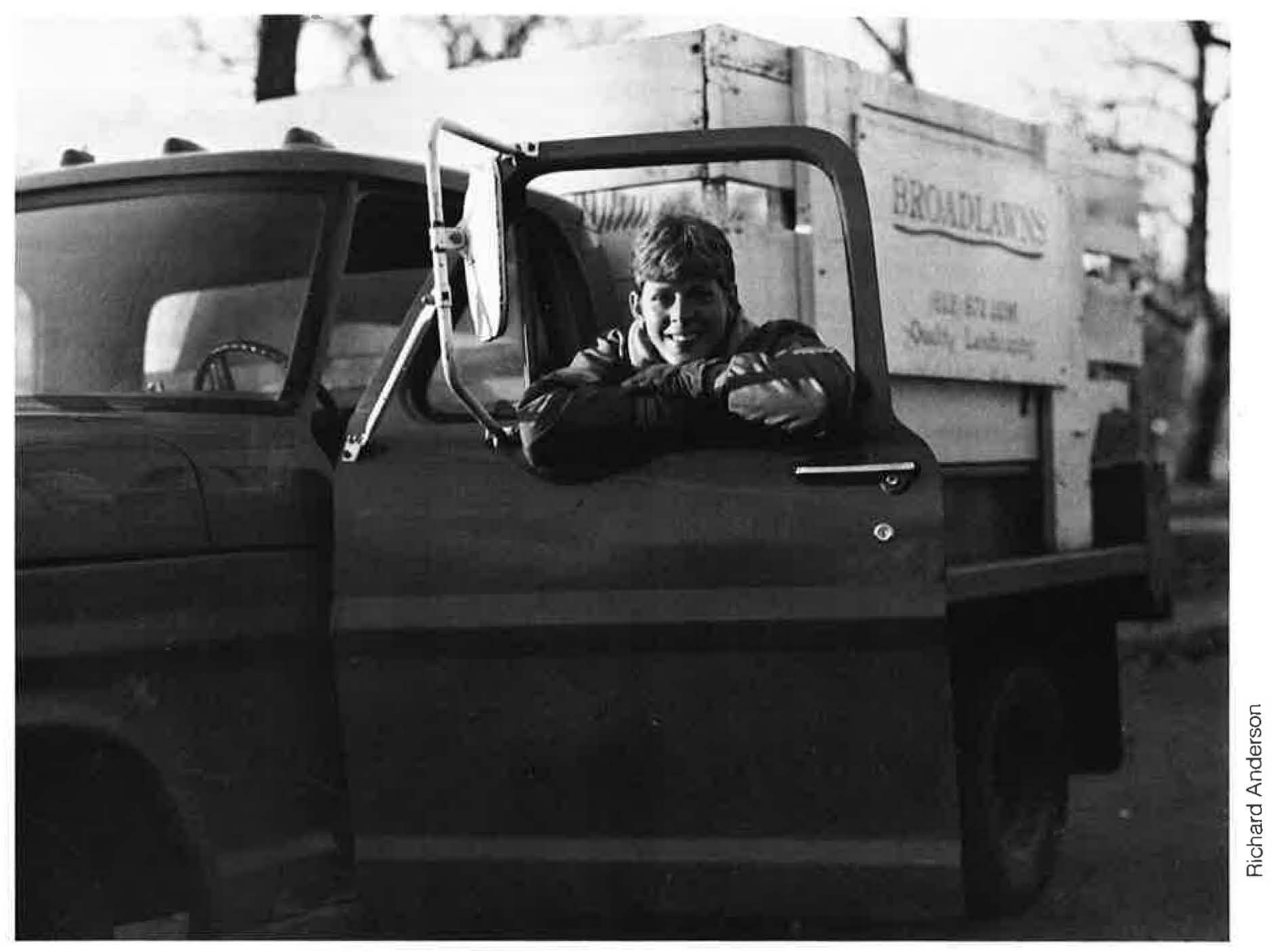

the numerous hurdles they will face, both personally and professionally, and be able to compete successfully in the marketplace. Third, they must help their clients address and overcome the gender-related obstacles that, as women, they will encounter in the business world.

2. Self-pacing and self-selection help women gain skills and confidence at the same time. At WomenVenture women are free to move ahead at their own pace and can exit (and reenter) the program at any point without feeling that they have failed. The "stepping" principal has been used both to divide the program's content into manageable elements and to provide financing in increments that prevent fledgling entrepreneurs from overextending themselves.

3. The best way to build client self-reliance is through participation in and exposure to good business practices. WomenVenture insists that clients develop a business plan (that includes the business' target market, funding requirements, performance expectations and at least a two-year projected cash flow) before they apply for credit. Even if WomenVenture provides the financing, clients are charged market rates of interest and are required to put up some collateral in order to receive loans. This puts the transaction on a firm business footing and prepares the client to operate as a business.

4. To effectively assist clients, programs themselves must practice what they preach; they too must operate in a business-like manner. Staff need to have a working knowledge of how to run a business, particularly how to project cash flow and assess working capital needs. Programs also must be realistic about what is possible within the current marketplace and keep attuned to its fluctuations.

5. To successfully assist low-income women achieve self-employment, programs must become agents of change. From the start, WEDCO/WomenVenture took an activist role within the community and, gradually, at both the state and national levels in order to change policies that limit womer's ability to become self-supporting. As part of this effort, WomenVenture has made very effective use of the media. This has helped them to increase public support for their program and recruit new clients as well as to influence public policy. 


\section{Notes}

a. U.S. Department of Labor, Bureau. of Labor Statistics, Handbook of Labor Statistics (Washington, D.C.: Government Printing Office, 1983) and U.S. Bureau of the Census, Statistical Abstract of the United States 1990 (Washington, D.C.: U.S. Government Printing Office, 1990)

b. Grossman, Allyson S., "More Than Half of All Children Have Working Mothers," Monthly Labor Review 105 (Feb 1982) as cited in Bianchi and Sprain, American Women in Transition (New York: Russell Sage Foundation, 1986) c. Statistical Abstract of the United States 1990

d. Blank, Rebecca M., "Women's Paid Work, Household Income, and Household Well-being," in The American Woman 1988-89, Sara E. Rix ed., (New York: WW. Norton \& Company, 1989)

e. U.S. Bureau of the Census, "Poverty in the U.S: 1985", in Current Population Reports, Series P-60, No. 158 (Washington, D.C.: Government Printing Office, 1987)

f. The State of Small Business: A Report of the President (Washington, D.C.: U.S. Government Printing Office, 1989)

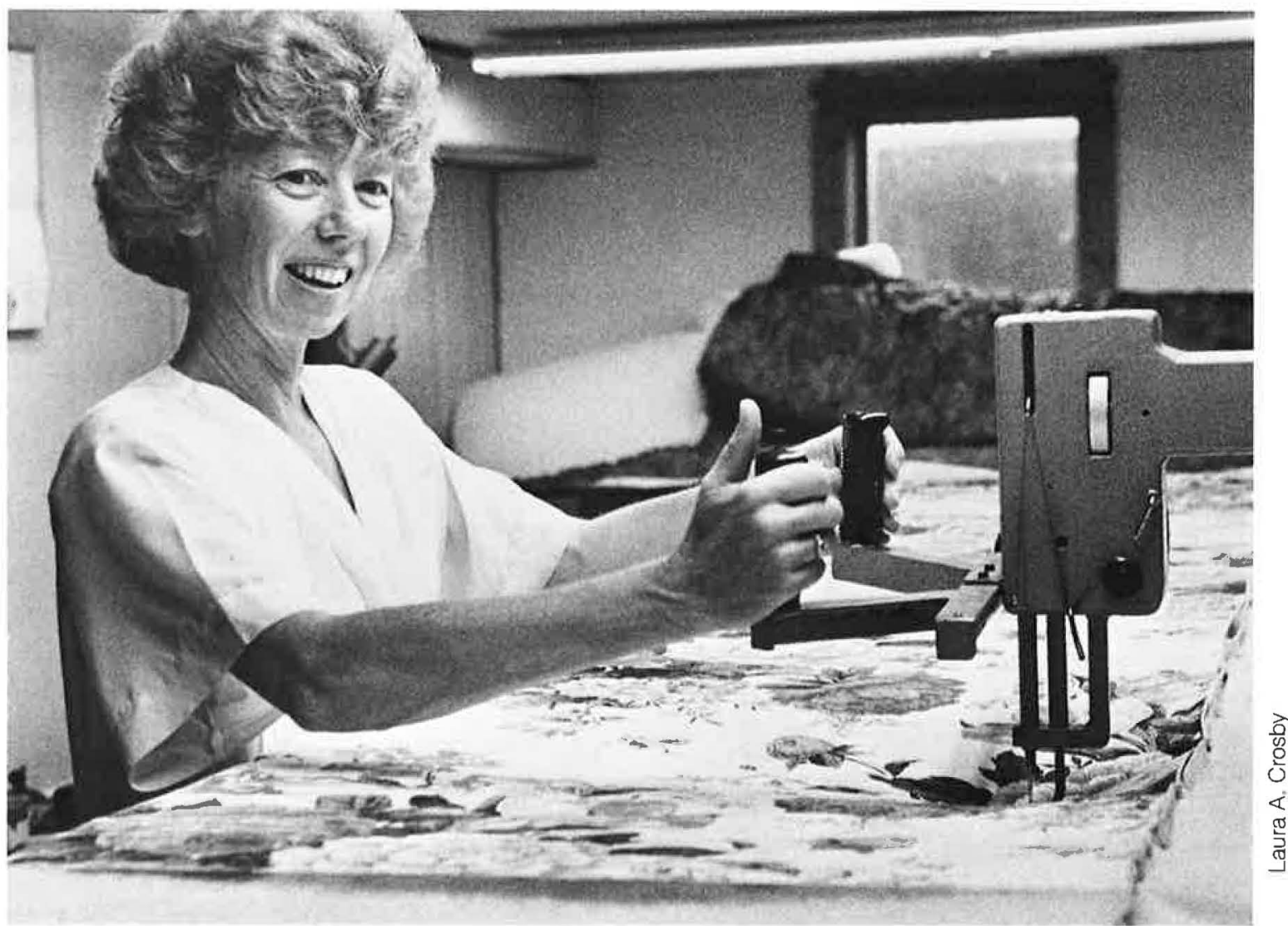




\section{Appendix}

The following is a sampling of microenterprise development programs in the United States selected to show the wide range of constituencies and geographic locations being served by such programs. A more comprehensive listing of U.S. programs can be found in the 1992 Directory of Microenterprise Programs listed under publications.

\section{Women's Self-Employment Project (WSEP) 166 West Washington, Suite 730 \\ Chicago, Illinois 60613 (312) 606-8255}

WSEP provides credit, technical assistance and training through an individual lending program, a group lending program (the Full Circle Fund) and an Entrepreneurial Training Program. WSEP's services are targeted to low and moderate income women in the Chicago area. Its goal is to assist these women to achieve self-sufficiency through self-employment.

\section{Coalition for Women's Economic Development (CWED)}

315 West 9th. Street, Suite 705

\section{Los Angeles, CA 90015}

(213) 489-4995

CWED provides credit and technical assistance services to low-income women in the Los Angeles area through a micro-business workshop, a solidarity circle program and a revolving loan fund. The solidarity circle program is modelled after Acción International's model which forms groups of borrowers in order to provide peer support and exchange and to encourage loan repayment.

\section{Good Faith Fund \\ 400 Main Street, Suite 118 \\ Pine Bluff, Arkansas 71601 \\ (501) 535-6233}

The mission of the Good Faith Fund is to widen the profile of future entrepreneurs to include women, minorities and dislocated workers through the delivery of credit and credit services and to raise the income levels of low-income and self-employed people. The Good Faith Fund was one of the first programs developed in the U.S. to test the Grameen Bank's (Bangladesh) grouplending model. Created in 1988, the Good Faith Fund currently offers group and individual loans to entrepreneurs in rural, sparsely populated counties within the state of Arkansas.

\section{Maine Displaced Homemakers Program Stoddard House University of Maine Augusta, Maine 04330 (207) 621-3432}

The program's primary goal is to help prepare disadvantaged women to participate fully in the state's changing economy through innovative preemployment and self-employment training and support services.

\section{The Lakota Fund \\ P.O. Box 340 \\ Kyle, South Dakota 57752 \\ (605) 455-2500}

Located on the Pine Ridge Indian Reservation, the Lakota Fund's mission is to support the development of private Lakota-owned and operated businesses on the reservation by providing financial and technical assistance and by fostering personal development. Its circle banking project uses a group lending methodology inspired in part by the Grameen Bank.

\section{Center for Community Self-Help 413 East Chapel Hill Street Durham, North Carolina 27701 (919) 683-3615}

Affiliated with the Self-Help Credit Union, this program is a partner with local organizations in the North Carolina Urban Microenterprise Program. The Center also provides small to medium-sized loans and technical assistance to businesses and projects that address the economic needs of rural, minority, female and low-income people in the state.

\section{Eastside Community Investments (ECl) 3228 East 10th. Street Indianapolis, Indiana 46201 (317) 633-7303}

ECl's goal is to create jobs and improve the quality of housing in a disadvantaged section of Indianapolis. It has pioneered an innovative self-employment program for day care providers and also is a participant in the demonstration program to provide self-employment services to women on AFDC.

Women's Initiative for Self-Employment (WISE)

P.O. Box 192145

San Francisco, California 94119

(415) 512-9471 
WISE links lower-income women with skills, information and financing to help them support small and micro-enterprise business development. It also works to remove institutional barriers that prevent women's equal participation in the economy

\section{Other Organizations that Provide Information on Self-Employment and Microenterprise Development in the United States}

\author{
Association for Enterprise Opportunity \\ 320 No. Michigan Avenue \\ Suite 804 \\ Chicago, Illinois 60611 \\ (312) 357-0177
}

The Corporation for Enterprise Development 777 North Capital Street, NW.

Suite 801

Washington, D.C. 20002

(202) 408-9788

The Self-Employment Learning Project

1333 New Hampshire Avenue, N.W.

Suite 1070

Washington, D.C. 20036

(202) 736-5807

Women's Economic Development Program . .... The Ms. Foundation

141 Fifth Avenue, 6th. Floor

New York, New York 10010

(212) $353-8580$

\section{Publications}

Please contact publishers directly to ascertain availability, cost of publications and/or shipping charges.

The Business of Service Business, The Business of Small Business, The Business of a Professional Practice, and Loan Fund Manual [available in Fall 1993] (WomenVenture, 23-24 University Avenue, Suite 200, St. Paul, Minnesota 55114, USA. Telephone: (612) 646-3808; FAX: (612) 641-7223)
The Business of Self-Sufficiency: Microcredit in the United States, by Valjean McLenighan and Jean Pogge, 1991. (Woodstock Institute, 407 South Dearborn, Chicago, Illinois 60605, USA. Telephone: (312) 427-8070)

Enterprising Women: Local Initiatives for Job Creation, 1989. (OECD Publications Service, 2, rue André-Pascal, 75775 PARIS CEDEX 16, France)

1992 Directory of Microenterprise Programs, Margaret Clark and Tracy Huston, eds., 1992. (SelfEmployment Learning Project, The Aspen Institute, 1333 New Hampshire Avenue, N.W., Suite 1070, Washington, D.C. 20036, USA. Telephone: (202) 446-6410; FAX: (202) 467-0790)

Hopeful Change: The Potential of Micro-Enterprise Programs as Community Revitalization Intervention, by Jacqueline Novogratz, 1992. (The Rockefeller Foundation, 1133 Avenue of the Americas, New York, New York 10036, USA. Telephone: (212) 869-8500)

Opening the Marketplace to Small Enterprise: Where Magic Ends and Development Begins by Ton de Wilde, Stijntje Schreurs with Arleen Richman, 1991. (Kumarian Press, 630 Oakwood Ave., Suite- 119, West Hartford, Connecticut 06110-1529, USA: Telephone: (203) 953-0214; FAX: (203) 9538579)

Widening the Window of Opportunity: Strategies for the Evolution of Microenterprise Loan Funds prepared by Shorebank Advisory Services, Inc., 1992. (The Charles Stewart Mott Foundation, Mott Foundation Building, Flint, Michigan 48502-1851, USA. Telephone: (313) 238-5651)

Women's Ventures: Assistance to the Informal Sector in Latin America by Marguerite Berger and Mayra Buvinic, 1989. (Kumarian Press, West Hartford, Connecticut [see address above]) 
Design: Ann Leonard

Cover Photo: Laura A. Crosby

Typography: Village Type \& Graphics

Printing: Graphic Impressions

\section{Other Editions of SEEDS Currently Available}

No. 2 Hanover Street: An Experiment to Train Women in Welding and Carpentry-Jamaica (English, Spanish)

No. 3 Market Women's Cooperatives: Giving Women Credit-Nicaragua (Spanish)

No. 4 Women and Handicrafts: Myth and Reality-International (English, Spanish, French)

No. 5 The Markala Cooperative: A New Approach to Traditional Economic Roles-Mali (English, French)

No. 6 The 1 .

Chat

No. 7 Deve

(Eng

No. 8 Cor

Me:

No. 9 The

$-\mathrm{J}$

No. 10 For pat

HQ McKee, Katherine.

1870.9 Self-employment as

. 543 a means to wornen's

no.15 economic

No. 11 Po

self-sufficiency

(En

No. 12 The

No. 13 Chil

POPULATION COUNCIL LIBRARY

NEW YORK

No. 14 Bre

We.

GAYLORD $S$

If you would like additional copies of this issue or any of the editions of SEEDS listed above, please write to us at the address given below. Copies of selected SEEDS issues in local languages are currently being published by organizations in the following countries: Egypt, India, Indonesia, Kenya, Nepal, Pakistan, Thailand and Vietnam. Please write to us for more information if you are interested in these materials.

$$
\begin{gathered}
\text { Ann Leonard, Editor } \\
\text { SEEDS } \\
\text { P.O. Box } 3923 \\
\text { Grand Central Station }
\end{gathered}
$$

New York, New York 10163, U.S.A. 


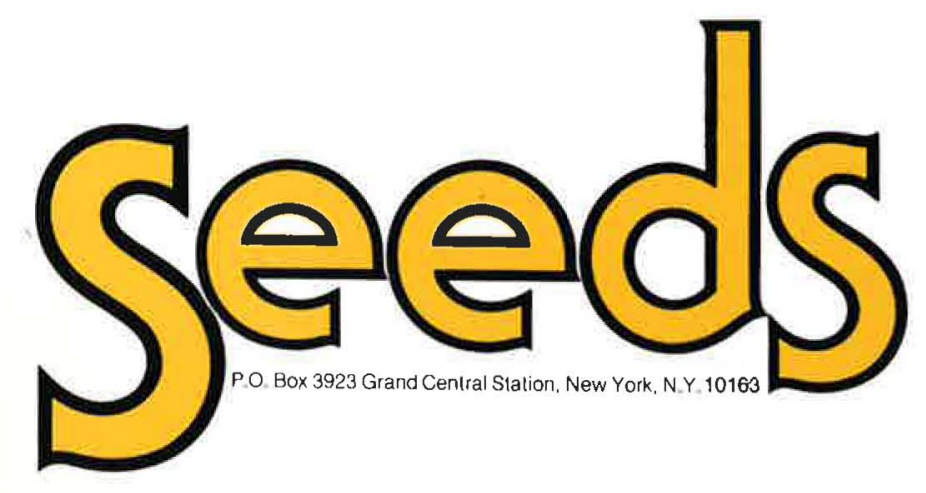

